\section{Comunicar Ciência por Joaquim Luís Faria}

Perante a atual crise epidémica, a comunicação científica ganha um particular relevo na sociedade. A palavra ciência vê-se frequentemente introduzida a pretexto para se atingir a atenção do grande público, fruto da dificuldade patente dos líderes em definir um conjunto de ideias simples e básicas que possam ser assimiladas globalmente.

Neste contexto, ressurge a questão de perceber qual a contribuição da comunicação de ciência [1]. Principalmente no estabelecer de diálogos acessíveis sobre questões sóciocientíficas críticas com um público maioritariamente não especializado. Como podem os peritos e os investigadores contribuir para um discurso público e democrático inteligível, indo para além do seu compromisso individual como cientistas?

Peritos e especialistas são (agora mais que nunca) procurados para dar respostas, comunicar ideias, emitir pareceres e ajudar em decisões difíceis. Alguns são até os mesmos peritos que há pouco tempo eram tratados paternalisticamente, para não dizer meramente tolerados, quando questões de impacto ambiental e saúde pública igualmente críticas dominavam as agendas políticas e sociais. A questão da competência destes especialistas é um tema complexo e apaixonado que oscila entre a sacralização e a demonização, deixando pouco espaço para uma discussão racional e informada [2]. Sobretudo em alturas de crise é necessário estabelecer uma dinâmica de confiança entre cientistas, investigadores, médicos, engenheiros e o público em geral: quando a cada hora, ou mesmo a cada minuto, somos bombardeados por uma quantidade imensa de factos, é necessário saber o que daí é realmente informação, como essa informação transmite conhecimento, e como com base nesse conhecimento podemos tomar melhores decisões para nós, a nossa família, a nossa comunidade, o nosso país.

0 nível de intervenção mais fundamental começa obviamente com a preparação dos nossos jovens para assimilar o discurso científico. Essa intervenção tem de começar nas escolas, e ser suportada por ações governamentais e não governamentais. Concursos promovidos por sociedades científicas, como a SPQ, contribuem de forma indelével na atração dos jovens e dos que the são próximos para a esfera da comunicação científica (são exemplo, as Olimpíadas de Química e o ChemRus). Projetos independentes como o WaterCircle [3] foram implementados em escolas secundárias com jovens adolescentes, seguindo uma abordagem de pesquisa participativa, com intervenção na escola e na comunidade, recorrendo a populares ferramentas online. Para os professores, as ações de formação da SPQ com uma forte componente de responsabilidade civil (Conhecer a Luz para uma Cidadania Ativa, CCPFC/ACC-104322/19) tentam aproximar o discurso simbólico da química e o léxico da rotina diária (onde termos como catálise e sinergia já contagiaram o discurso popular).

Um nível distinto envolve a comunicação de ciência para empresários, autarcas e políticos. A mensagem científica tenta aqui elencar uma cooperação multilateral, com vista ao bem comum e ao desenvolvimento sustentado. A outro nível, a comunicação científica entre pares está também ela atreita a dificuldades nestes tempos. A escrita científica através das publicações especializadas segue o seu curso lógico numa direção de acesso não discriminado a uma ciência aberta. Para além da escrita existe toda uma atividade de eventos científicos que tem também de se adaptar a uma nova lógica de comunicação. Neste aspeto, a SPQ depende em muito dessa adaptação, pois grande parte da sua atividade passa por essa via.

À parte de veículos de comunicação e níveis de inter-relacionamento, aos jovens investigadores é cada vez mais necessário desenvolverem competências que Ihes permitam articular a sua investigação num discurso convincente e acessível a um público não científico. Estabelecer estratégias eficazes de comunicação científica deve fazer parte dos objetivos da sua formação. A comunicação capaz do conhecimento cientíico é imprescindível para que as populações adotem comportamentos individuais e coletivos de forma consciente. Para os investigadores, poderá no limite permitir influenciar e definir políticas científicas.

[1] S. Molthagen-Schnöring, Communicating Science in Covid Times, HTW Berlin, 2020, DOI: 10.5281/zenodo.3956336 (acedido 1/11/2020).

[2] T. M. Nichols, The death of expertise: the campaign against established knowledge and why it matters, New York, NY: Oxford University Press, 2017.

[3] R. R. Marques, C. Malafaia, J. L. Faria, I. Menezes, Environ. Educ. Res., 2020 26, 1043-1059. DOI: 10.1080/13504622.2020.1776845.

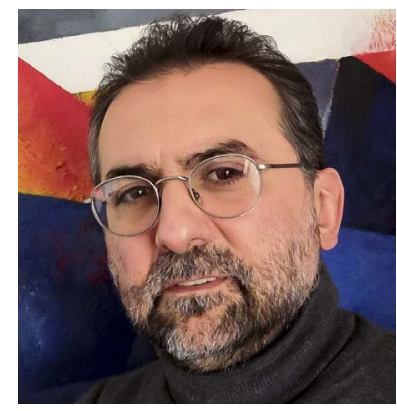

\section{Joaquim Luís Faria}

Vice-Presidente SPQ. Professor Associado da FEUP. Investigador do LSRE-LCM. Responsável pelo curso Comunicação de Ciência para Audiências Não Especializadas da Unidade de Formação Contínua da FEUP. jlfaria@fe.up.pt ORCID.org/0000-0002-6531-3978 